OPEN ACCESS

Edited by:

Jan Matti Dollbaum,

University of Bremen, Germany

Reviewed by:

Huseyn Aliyev,

University of Glasgow,

United Kingdom

Adrian Florea,

University of Glasgow,

United Kingdom

*Correspondence:

Hilmi Ulas

ulas@chapman.edu,

orcid.org/0000-0001-5759-539X

Specialty section: This article was submitted to

Peace and Democracy, a section of the journal Frontiers in Political Science

Received: 12 June 2021 Accepted: 22 October 2021 Published: 12 November 2021

Citation:

Ulas H (2021) The Dynamics of Social Movements in Unrecognized

States-A Comparative Study.

Front. Polit. Sci. 3:724125.

doi: 10.3389/fpos.2021.724125

\section{The Dynamics of Social Movements in Unrecognized States-A Comparative Study}

\author{
Hilmi Ulas * \\ Department of Peace Studies, Chapman University, Orange, CA, United States
}

In the political realm, our world is currently experiencing both a massive decline in democracies as well as the quality of democratic regimes in all geographical regions, and a rise in pro-democracy social change movements. Meanwhile, extant scholarly research emphasizes that social movements can contribute to changes in political regimes, such as the undermining of authoritarian ones or simply causing a circulation of the elite. Nevertheless, there is a gap in the scholarly knowledge regarding when political activism becomes effective or can even take place without total annihilation in the context of unrecognized states. To address this gap, studying cases of pro-democracy movements in unrecognized states through a comparative schema is the most effective methodology. In these cases, some variables that affect movement outcomes, such as international diplomatic relations, NGO activity, multinational company pressures, etc. are more restricted due to these states lacking official diplomatic capacity. Therefore, in unrecognized states, domestic political-economic factors are primal and their effects can be observed much more easily, which then lends some tentatively generalizable insights as well. For the purposes of this paper, I will consider the emergence and ultimate outcomes of pro-democracy movements in three unrecognized states: North Cyprus, Abkhazia, and Taiwan. All three cases in comparative perspective can shed light on the dynamics of how nonviolent, pro-democracy movements unfold under the authoritarian-leaning settings of unrecognized states with minimal international interaction or oversight.

Keywords: social movement, democratization, Cyprus, taiwan, abkhazia, transnational activism, international engagement

\section{INTRODUCTION}

Nonviolent social change movements, while systematically inquired into since the 1960s, have garnered considerable attention since the Arab Spring events of 2011, where entrenched autocracies were targeted and democratization in the region gained steam. This provided hope that authoritarian governments can be defied and democracy can be achieved even where the pre-existing regional democratic capacity is questionable (Vidwans, 2020). On the one hand, only the Tunisian case has been a sustainable success, whereas Egypt-another famous case-only saw some limited reforms. On the other hand, cases such as Bahrain led to heavy repression and failure, while the Yemeni, Libyan, and Syrian movements have instead led to civil wars. As such, one question still remains dominant in the field: can nonviolent social movements be effective in enacting change where their opponents are authoritarian governments? 
This question is especially prominent in the current political realm: our world is experiencing both a massive decline in democracies as well as the quality of democratic regimes in all geographical regions (Carothers and Press, 2020; Repucci and Amy, 2021), and a significant increase in political social change movements (Cordenillo and Van der Staak, 2014; Burcher, 2017). Meanwhile, extant scholarly research emphasizes that social change movements-ranging from completely violent to entirely non-violent-can contribute to changes in political regimes, such as the undermining of authoritarianism or simply causing a circulation of the elite (Hallward and Norman, 2015; Freeman-Woolpert, 2017; Sa'di, 2015; Chen and Moss, 2018; Brancati, 2016; Aleman, 2015; Dahlum and Tore, 2019; Lee, 2010). Nevertheless, there is a gap in the scholarly knowledge regarding when political activism becomes effective or can even take place without total annihilation under authoritarian regimes. This especially holds true regarding the same dynamics within the context of unrecognized states; in fact, there is no systematic study of how and why pro-democracy movements emerge or succeed in these cases.

To address this gap, this paper provides case studies of unrecognized states where pro-democracy movements emerged and an analysis of what we can learn regarding the dynamics driving and the ultimate success or failure of said movements. Unrecognized states are those that possess some measure of $d e$ facto sovereignty over territories otherwise legally claimed by another, recognized state (labeled as "the parent state" in this context); as such, they lack de jure sovereignty. Even in cases where they achieved eventual democratization, unrecognized states have invariably experienced at least a long period of authoritarian or semi-authoritarian rule accompanied by militarization. Such centralized power and armed power invariably appeared necessary for unrecognized states to perpetuate their jeopardized existence against a parent state aiming to reclaim their territories. Moreover, in these cases, variables such as international diplomatic relations, NGO's political activity, multinational company pressures, etc. can be either eliminated or much more restricted due to these states lacking official diplomatic capacity and actors attempting to refrain from providing inadvertent recognition. Therefore, in unrecognized states, domestic political-economic factors as well as the sponsor state-unrecognized state relations are primary and their effects on these cases can be observed more easily.

For the purposes of this paper, I consider the emergence and ultimate outcomes of pro-democracy movements in three unrecognized states, which exhibit high levels of similarity, over time: North Cyprus ${ }^{1}$, Abkhazia, and Taiwan ${ }^{2}$. The pro-

\footnotetext{
${ }^{1}$ While North Cyprus is generally coded as free or semi-free (see for example (Northern Cyprus Country Report 2002, 2003; “; Northern Cyprus Country Report 2011, 2012)), I have argued elsewhere that the system is inherently flawed and there is such widespread intervention as to render the state a puppet that ignores popular will that coding it mostly authoritarian is appropriate (see (Ulas 2017)).

${ }^{2}$ Taiwan is generally seen as a partially-recognized state but categorically, given the lack of official recognition by most UN states, Taiwan is coded as part of the Universe of unrecognized states. See (Caspersen 2012; Ulas 2017).
}

democracy movements in all three cases followed differing trajectories: the Northern Cypriot case went through a pendulum of failure-minimal success-backlash; the Abkhazian case remained only performative; and the Taiwanese case went from repression (during widespread recognition) to resounding success (while unrecognized). All three cases in comparative perspective can shed light on the dynamics of how nonviolent, pro-democracy movements unfold under in the context of unrecognized states as they experience changes along the authoritarianism-democratization continuum over time. Through these case studies, I demonstrate how economic factors and international relations, rather than the authoritarian or democratic nature of a regime, predict the emergence and success of sustained pro-democracy movements in the context of unrecognized states.

\section{LITERATURE REVIEW}

This inquiry into the dynamics driving the occurrence and success of pro-democracy movements in unrecognized states that shuttle between authoritarianism and democratization due to internal and external factors ${ }^{3}$ must necessarily start with a review of the literature. Given this, there is a dearth of works on pro-democracy movements in unrecognized states; as such, this literature needs to be synthesized with and supplemented by a review on social movement theories, as well as authoritarianism and pro-democracy movements. Specifically, this paper reviews the state of scholarly knowledge on movement onset, success, and failure, as well as authoritarian stability within both a more general context, as well as the specific context of unrecognized states. Ultimately, this literature review serves to create the background and a framework for inquiring into the prowess of pro-democracy movements in unrecognized states.

Currently, social movement generally fall along the fault-lines of structural/relational or cultural/emotional emphases (Buechler, 2011). The main competing ideas are Resource Mobilization Theory (McCarthy and Zald, 2001; Tilly, 1978; 1992), Political Process Theory (PPT) (Tilly, 2000, 2003, 2004a; Della Porta and Tarrow, 2004) and Framing Theories. Of these, PPT is the one adopted in this paper as it is both a multilevel approach and this study examines variables at multiple analytical levels; and PPT is an attempt to synthesize the theories in the field, which allows us to tap into the varied approaches in the field at once. PPT emphasizes "political opportunity, mobilizing structures, and framing processes" whereas culture and contentious repertoires play a minor role (Buechler, 2011, 208). Political opportunities here refer to openings to encourage elite defections, decline in authoritarian capacity, international support, etc. that allow to build momentum for a movement (Goldstone 2004; Skocpol, 2006). Meanwhile, mobilizing structures involve existing formal or informal social networks that can be utilized to galvanize and sustain participation in the

${ }^{3}$ For more on this, see: (Caspersen 2011b; Voller 2015; Kopeček, Hoch, and Baar 2016; Ulas 2017). 
movement. Framing processes allow not only an awakening towards common interests and goals but also the creation of strong collective identities to generate support for the movement. In the modern social movement theories, the framework predicts that political opportunities are necessary yet insufficient indicators of movement emergence, maintenance, and success. Indeed, a movement's capacity to get people's support through framing and get them to overcome the barriers to participation by actively tapping into mobilizing structures appears to be just as important. Considering pro-democracy movements in unrecognized states, then, one can predict that the theory would focus on weaknesses in authoritarian power, changes in the international context, and the movement's ability to bring the opposition together through identity politics or economic incentives (such as increased trading opportunities through democratization) as the main approach to promoting movement success.

Authoritarianism is a form of government where individual freedoms, political rights, and civil liberties are heavily restricted and where the use of repression promotes high levels of obedience towards the state (Della Porta et al., 2014; "Understanding and Challenging Authoritarianism," 2017). As such, socio-political dissent tends to be heavily discouraged in authoritarian states (Della Porta et al., 2014; Chen and Moss, 2018; Sa'di, 2015), which is why the larger question of how pro-democracy movements can succeed under significantly adverse circumstances is expedient. However, it is important to note that despite common generalizations, authoritarian states are not monolithic; in fact, neither are all authoritarian states opposed to all forms of dissent, nor do they always employ violent forms of repression (Chen and Moss, 2018).

Authoritarian regimes, which are well-established and wellconsolidated, hold advantages that undermine pro-democracy movements. Firstly, they tend to have a wide repertoire of repression, including the use of education and media to promote obedience (Della Porta et al., 2014; Chen and Moss, 2018). Moreover, their repressive mechanisms can be formal (such as the use of police forces) or informal (such as the use of thugs) (Della Porta et al., 2014; Chen and Moss, 2018). Importantly, open (and potentially legalized) repression can force anti-regime/pro-democracy movements to go underground or online (Groves, 2012; Pinckey, 2020). Secondly, authoritarian regimes create, reinforce, and maintain elite and oligarchic networks through patron-client relations, whereby the power-holders and power-brokers of autocracies tend to support the regime for their common interests (Facal and Estrelita, 2020). Thirdly, autocracies tend to create a tight military-state relationship, which significantly reinforces the repressive capacity of the state (Della Porta et al., 2014; Chen and Moss, 2018; Sa'di, 2015). Occasionally, the state is also able to benefit from a "national hero" narrative where the authoritarian leaders are perceived as the heroes of a liberation struggle (Dendere, 2019). Additionally, autocracies tend to also promote a robust public sector, which allows them to exert control over their own population by making the latter dependent on the state for their livelihood and economic survival (Isachenko, 2012).
Given all the factors outlined above, which should eliminate the possibility of any pro-democracy movement, how do such movements occur-and even succeed? Firstly, it is important to recognize that pro-democracy movements are not monolithic. Indeed, the formation, mobilization, goals, and power of a prodemocracy movement will necessarily alter according to local factors: historical context; state-society relations and societymovement relations; and the repressive repertoire of the state (Chen and Moss, 2018; Sa'di, 2015). Importantly, legitimacy is a key word: whether the repression as well as the state are seen as legitimate or not either reinforce or undermine the regime's capacity to repress and depends, in turn, on a delegitimizing framing (Della Porta et al., 2014; Jackman, 2020). However, even regimes known to be corrupt and thus illegitimate appear able to keep power through patronage networks and sustain repressive capacities allowing for the suppression of movements. This, in turn, conforms with extant theories: framing is not the primary factor in predicting movement emergence.

Which takes us to the first important factor in reinforcing prodemocracy movements: the decline and/or failure of traditional repressive mechanisms serves as an ideal opportunity window for these movements (Skocpol, 1979; Della Porta et al., 2014; Sa'di, 2015). These opportunities can emerge if state-elite or statemilitary interests fall out of alignment and the pro-democracy movement obtains access to these potential elite or military defectors (Skocpol, 1979; Tilly, 2004a; Della Porta et al., 2014). Additionally, economic crises serve as a way to undermine repression by crippling the regime's ability to maintain patron-client relations as well as bloated levels of public sector hiring (Heydemann and Leenders, 2013; Facal and Estrelita, 2020; Chen and Moss, 2018; Sa'di, 2015; Della Porta et al., 2014). Nevertheless, opportunity windows alone cannot explain mobilization or success-so what does?

Most research underlines a few key factors that allow for the emergence of pro-democracy movements under authoritarian regimes. The increased mobilization of youth, who believe the risks of protest are outmatched by potential benefits (as well as perceived costs of the status quo) and who feel less ingratiated for liberation and war heroism, can increase the movement's chances if the movement can recruit these "free radicals" (Jackman, 2020). An economic downturn, which can shrink opportunities available to the youth while also increasing unemployment, can reinforce youth mobilization as the relative costs of protest will decline (Brancati, 2016; Carothers and Press, 2020). Furthermore, cyberspace and online platforms have allowed for prodemocracy movements to emerge and mobilize virtually-although this is a space susceptible to state control-as well (Dendere, 2019; Pinckey, 2020). Importantly, if community elders who want to support a better future for the youth also mobilize, pro-democracy movements become inevitable (Groves, 2012; Guzman-Concha, 2012; Cini and Guzmán-Concha, 2017; Dendere, 2019; Jackman, 2020). Additionally, as noted above, not all forms of dissent are discouraged under autocracies; in fact, social dissent is usually allowed where political dissent is not (Chen and Moss 2018). Therefore, there are ample opportunities under authoritarian regimes for the practice of popular agency at micro and meso 
levels of society (Della Porta et al., 2014; Chen and Moss, 2018). Such agency allows for movements to build capacity for further, larger, and potentially political mobilization thus building mobilization structures as a resource (Petras and Veltmeyer, 2011; Sa'di, 2015).

Pro-democracy movements can also benefit from their association with political opposition parties/formal networks, but there are caveats here. Firstly, while opposition parties are wont to support pro-democracy movements when not in power, they are just as likely to discourage these "radical" movements once in power (Pinckey, 2020; Della Porta et al., 2014; Chen and Moss, 2018; Sa'di, 2015). Secondly, opposition parties may also attempt to co-opt, subsume, and thus undermine some key players in the movements that brought them into power (Pinckey, 2020; Della Porta et al., 2014; Chen and Moss, 2018; Sa'di, 2015). Moreover, once movements are subsumed by politics, they become routinized actors rather than subversive ones, losing much of their impact and creativity that initially allowed them to defy authoritarian governance (Pinckey 2020; Della Porta et al., 2014; Chen and Moss, 2018; Sa'di, 2015). Nevertheless, having close networks with defecting political elite might be a necessary yet insufficient component of a successful pro-democracy struggle in an autocracy.

Transnational dynamics also house factors that are important to the success or failure of pro-democracy movements (Chen and Moss, 2018; "Understanding and Challenging Authoritarianism," 2017; Bursztyn et al., 2021; Smith and Wiest, 2012). The most pertinent aspect here has been the occurrence of a tectonic shift in the global order from the power and legitimacy of a state being based on territorial control to one where power and legitimacy are rooted in a state's capability to conform to normative international standards (Smith and Wiest, 2012; Bursztyn et al., 2021). In fact, this new paradigm of legitimacy and power is called sovereignty as responsibility and is rooted in the globalization of human rights as standard norms (Etzioni, 2006; Bellamy, 2009; Deng et al., 2010; Moses, 2014). Subsequently, this has meant that the state's ability to use coercion has declined whereas their need to conform to international laws and standards has increased (Berg, 2009; Berg and Molder, 2012; Smith and Wiest, 2012). Therefore, we can argue that international dynamics have become more accommodating and, in fact, supportive of pro-democracy movements. Moreover, the more interconnected a movement is with its international counterparts, the more it will be empowered. This empowerment comes from an increase in transnational knowledge sharing and support in logistical terms, and increased pressure on the state (Smith, 1998; Della Porta and Tarrow, 2004; Johnston and Paul, 2006; Bakker and Frank, 2016; Understanding and Challenging Authoritarianism, 2017). This also means that less interconnected movements might not benefit much from transnational dynamics. In addition, transnational networks vary in intensity and commitment despite their potential role in increasing movement capacity (Smith and Wiest, 2012; Bursztyn et al., 2021). Furthermore, movements inspired by other international examples might imitate tactics without a thorough understanding and the prerequisites build up, which lowers their chances of success
(Vidwans, 2020). Ultimately, we can conclude that transnational dynamics help empower movements in direct correlation with the level of interconnectedness between transnational networks and the local pro-democracy movement. This also holds true regarding the democratization of unrecognized states.

The democratization of unrecognized states is significantly correlated with the perception of the need to democratize by the power-holders for these states for the purposes of regime survival and, ultimately, gaining recognition (Mulaj, 2011, 47; Caspersen, 2011b; Ulas, 2017). Meanwhile, these states depend largely on their sponsors for the former goal whereas they depend on the international community for the latter (Caspersen, 2011b; Ulas, 2014, 2017; H.; Lin, 2016; Isachenko, 2012; Harvey and Stansfield, 2011; Closson et al., 2013). This means that the requisite dependence on the populace and the subsequent give-and-take between the rulers and the ruled (as outlined by Tilly, 1992) is largely undermined in these contexts (Ulas, 2017). Given this lack of dependence of the state on the populace, can there be a role for social movements and civil society in promoting democracy?

The literature on the democratization of unrecognized states has produced four frameworks that can help understand the role pro-democracy movements may play in unrecognized states. Ulas's framework (Ulas, 2017, 427-35), which will be adopted in this study, is largely a synthesis of the other three frameworks proposes by Caspersen, Kopecek et al., and Voller (Caspersen, 2011b; Voller, 2015; Kopeček et al., 2016) together with theories of democratization. According to the framework, unrecognized states (and any other state suffering a similar condition) experience-at least at inception-acute threat perceptions which push towards hyper-militarization, repression of dissent, and the systemic promotion of internal unity. During this time, so long as the regime can absorb economic shocks (through trade, external aid, or domestic economic performance) and/or maintain a high repressive capacity, in addition to providing positive economic incentives to provide for basic human needs and to co-opt opposition, then the regime will remain stable. The main mechanisms of pro-democracy change in these cases were: significant systemic shocks beyond the capacity of the state and external aid to accommodate; changes in the international context (switch to emphases on earned sovereignty and human rights over Cold War alliances) and economic shocks reducing repressive capacity; contentious repertoires and institutional legacies; and last but not least, an active enough civil society of both formal and informal networks to mobilize to take advantage of the opportunity window (Ulas 2017, 428). Another important factor in these cases was international scrutiny and engagement; the former caused the state to be less repressive (or less brazenly so), whereas the latter provided hopes for an alternative and more prosperous future through democratization (Ulas 2017). This framework overlaps significantly with the dynamics of pro-democracy movements in authoritarian settings as underlined above; moreover, the factors identified through the literature review thus far are in accord with the framework of social movement emergence and success as proposed in the Political Process Theory (McAdam, 2010; Tilly, 2000; 2003; 2004b). 


\section{METHODOLOGY AND CASE SELECTION}

Generating an understanding of the dynamics driving prodemocracy social movements in unrecognized states requires inquiries into the existing cases of such phenomena. Given this, there is a dearth of existing scholarly knowledge regarding the dynamics of these movements in unrecognizes rates; as such, the case studies will naturally be exploratory rather than explanatory, as causal relationships cannot be drawn based on the limited academic knowledge of this phenomenon. Moreover, case studies naturally generate knowledge that is context-specific. Instead, this paper addresses this methodological weakness by utilizing a comparative case study approach. On this note, this work will be richly descriptive in covering the dynamics of the chosen cases in order to uncover similarities and differences that have marked the emergence, persistence, and success/failure of pro-democracy movements in unrecognized states across the past several decades. Additionally, in unrecognized states, one can specifically observe how much impact several factors, such as dependence on an external actor, international engagement (esp. economic), international norms, and international scrutiny, can have on movement onset, sustainability, and success.

Unrecognized states are entities that have unilaterally seceded from a recognized parent state, asserting control over territories whose ownership is under dispute between the entity and its parent state (Caspersen, 2012; Ulas, 2017). Therefore, unrecognized states tend to be in a prolonged state of conflict, which pushes them towards militarization and authoritarianism (Caspersen, 2011a; Ulas, 2017). Indeed, especially early after their establishment, unrecognized states tend to be on the higher spectrum of authoritarianism. Moreover, unrecognized states have de facto sovereignty but lack de jure sovereignty, meaning that they have limited interaction and interconnectedness with the international community, especially at the diplomatic and economic levels. Even NGOs are unlikely to engage unrecognized states on political topics such as peace-making in order to avoid accidentally providing implied recognition (Wolff, 2011; Ulas, 2016). This diplomatic and economic isolation in turn make unrecognized states dependent on external sponsor states for their survival - more so than their own people or good relationships with other states (Caspersen, 2008; Kamilova and Berg, 2012). This provides for an exceptional authoritarian setting in which to study the role of the economy and international interactions in dictating the success of pro-democracy movements.

Unrecognized states almost invariably suffer from a period of authoritarianism (Caspersen, 2011a, 2011b; Isachenko, 2012; Ulas, 2017). In addition, their economies as well as diplomatic relations tend to be heavily regulated due to their political, economic, and social isolation, which eliminates or severely weakens the influence of several variables such as the role of trade relationships in providing opportunities for movements. This, then, allows for the study of unrecognized states and hypothesize on the importance of the missing variables for the success of pro-democracy movements. In addition, for the present study, I have chosen three cases that feature multiple outcomes for pro-democracy protests: Abkhazia, where two prodemocracy revolutions took place without visible gains; North Cyprus, where one pro-democracy revolution took place, others were suppressed, and where there are ongoing protests; and lastly Taiwan, where an initial pro-democracy movement was heavily suppressed only for its successor to help produce one of the most stable and advanced democracies around the globe. These cases also constitute the three most prominent examples where prodemocracy movements have had considerable impact in unrecognized states.

The cases are both similar (political standing) and different (geography, GDP, size, relation with sponsor) in ways that allowed for more generalized conclusions to be drawn from the study while "controlling" for the factors where the cases differ (Mahoney and Rueschemeyer, 2003). Some important factors for comparison are as such: Abkhazia and North Cyprus suffer from complete economic and political isolation, whereby they have become mostly dependent on a sponsor state (Russia and Turkey, respectively). Meanwhile, Taiwan has partial recognition and its economy is well-integrated into global markets, although it is highly dependent on military support from its sponsor state (the United States). The comparisons among the three help explore the importance of the international community's engagement as both witness of and resource provider for social movements. At the same time, this article studies the effects of having an authoritarian government that is economically independent of its people but is dependent on outside actors on such movements, especially through the lens an alteration of regular state-society relations.

Since the movements under consideration in this paper are historical, the case studies primarily rely on secondary data. These data will include newspaper coverage, official documents, and $\mathrm{NGO/CSO}$ reports. In addition, the study also considers tertiary data such as op-eds and editorial works, testimonials, news commentaries, as well as existing academic analyses. A mixture of these data provides both a historicized context to the cases as well as a deep understanding of the apparent main dynamics that allowed at times for the success or repression of pro-democracy movements-and, at times, completely averted their occurrence despite conditions being met.

\section{CASE STUDIES}

\section{The Rise, Fall, and Re-Birth of Authoritarianism in Northern Cyprus}

Cyprus was an ex-Ottoman colony that was then colonized by the British, only to gain its independence in 1960. This newly independent state was called the Republic of Cyprus (RoC). According to the treaties, this was supposed to be a bicommunal constitutional republic where political power would be shared between the two main ethnic groups: Greek Cypriots and Turkish Cypriots. As with many other power-sharing arrangements, this republic fell apart quite fast: while the nature of the violence (whether it was a full-scale civil war or a limited communal strife) is disputed, there was nonetheless sporadic and sometimes widespread instances of violence that 
happened from December 1963 to August 1974. In the end, a unilateral Turkish intervention or invasion took place, dividing the island into two along what is now known as the Green Line. The Turkish Cypriot community was displaced to the north just as the Greek Cypriot Community was displaced to the South. As the status quo ante was never re-established, the Turkish Cypriots unilaterally declared their secession as well as their statehood in 1983. This new "state" was called the Turkish Republic of Northern Cyprus (TRNC), and it is an unrecognized pseudostate of about 500,000 people. The only state to recognize North Cyprus is Turkey, which acts as the sponsor state for the TRNC-meaning it provides the latter with diplomatic, economic, and military support, ensuring its continued survival.

Given that the state was established from the ashes of an ethnic strife that involved a militarized underground resistance organization (TMT), it is not a surprise that the resulting society was likewise militarized and duly hyper-nationalistic. This context allowed for one of the war heroes to take power in an authoritarian fashion (Isachenko, 2012; ilter and Alankuş, 2010; Duzgun, 2000). This hero, Denktash, became the president in 1983 and held onto power until he was eventually deposed in 2003. This 20-year period marked an era of stable authoritarianism in North Cyprus (Ulas, 2014; 2017).

Why was this authoritarian era so enduring? One of the reasons, especially for the older generation, was the implicit trust placed in Denktash as a result of hero worship (Isachenko, 2012; Adamides, 2015). Indeed, for many he could do no wrong despite obvious signs of corruption and profiteering (Duzgun, 2000). Secondly, there was economic stability that promoted authoritarian stability. This was partly due to the fact that many Turkish Cypriots are hired in a heavily-bloated government sector, which meant that they were dependent for their livelihood on networks of patronage (Gazetesi, 2011; Isachenko, 2012). Meanwhile, the government did not depend as much on taxes collected from its citizens as compared to the support coming in from Turkey, which virtually rendered all workers expendable. Therefore, everyone had to toe the line to be hired by the government and to keep their jobs, which undermined the potential for a protest movement to take place.

Furthermore, whenever economic crises occurred (which was often due to rampant corruption and fiscal mismanagement), Turkey would bail the authoritarian leadership out, fulfilling its role as the sponsor state (Ulas, 2017). This meant that patronage networks could be perpetuated and paid off for much longer than the coffers of a corrupt, authoritarian state should have allowed. In fact, economic crises tend to usher in an era of resistance, mostly due to the collapse of patronage networks (Ulas, 2017). By not allowing the escalation of this crisis through leveraging external fiscal support, the authoritarian Northern Cypriot government was able to endure in spite of its evident economic and political weaknesses. All in all, the authoritarian government exhibited no signs of change-until some tectonic shifts occurred in the international realm.

In 2000, a significant economic crisis occurred in Turkey, which was naturally reflected unto Northern Cyprus. There were two reasons for this: firstly, Northern Cyprus depended entirely on Turkish aid to pay for the wages of government employees, whereas the government sector was extremely bloated due to the selling of favors through unnecessary hiring practices. Without aid, paying worker's wages and maintaining the bloated patronage networks proved straining, if not impossible. Secondly, as the only state that recognizes Northern Cyprus, all external visitors and tourists arriving to North Cyprus have to go through Turkish airports and seaports. Moreover, much of the tourism in Northern Cyprus caters to Turks traveling to North Cyprus for beach and casino visits, and the tourism sector is the biggest income-generator in North Cyprus. Therefore, when Turkey experienced the economic crisis of 2000, the revenues of the Northern Cypriot tourism sector steeply declined. Given these two factors, North Cyprus experienced an unprecedented economic crisis; moreover, Turkey was no longer in a position to bail the government out of the crisis. Consequently, the wellestablished patronage networks started to show cracks and the seemingly unmitigable support for the ex-hero President Denktash started to collapse.

At the same time, the European Union (EU) started to play a more active role in both Turkey and Cyprus. Indeed, the RoC was promised membership to the Union by 2004 and it appeared highly likely that Turkey's bid for membership would also go through should it be able to help resolve the Cypriot conflict. Meanwhile, Turkish Cypriots had realized the precarity of depending on external aid for their economic survival; therefore, many labor unions as well as Turkish Cypriot activists also promoted peacebuilding so that Turkish Cypriots could enter the EU alongside the RoC and thus gain increased opportunities for trade and tourism (Guven-Lisaniler and Rodriguez, 2002; Yesilada and Sozen, 2002; Theophylactou, 2012). Concurrently, then-Turkish Prime Minister Erdogan started advocating for peace alongside much of the Turkish Cypriot civil society, as he saw the economic opportunities inherent in a potential EU membership (Theophylactou, 2012). This was a significant deviation from Turkey's prior position towards the conflict of no resolution without significant autonomy for Turkish Cypriots and some territorial control ceded to Turkey.

These changes in the Turkish Cypriot civil society and the Turkish approach to the Cypriot Conflict undermined the seat of the hyper-nationalistic president. Indeed, Denktash had come to depend on several factors to keep his monopoly on political power. Firstly, having a supposedly "eternal enemy" in the form of Greek Cypriots had made his nationalistic and anti-peace platform quite viable, whereby he had a stake in perpetuating the conflict. Now that the Turkish Cypriot majority supported economic prosperity through peace rather than perpetuating and pursuing the "National Cause" (i.e. the Cypriot Conflict), Denktash's platform started unraveling. Secondly, Denktash enjoyed the TRNC's status as an unrecognized state as the international community had little supervision over the territory's management, which promoted a lack of accountability. Subsequently the government could utilize corrupt policies openly to establish and maintain the patronage networks so essential for authoritarian stability. Moreover, Denktash and other associated "elites" exercised war profiteering in that they took over Greek Cypriot 
properties left in the North and distributed them in order to further finance their clientelism and their own pockets (Duzgun, 2000; Ulas, 2017). As such, increased international scrutiny within the recognized EU framework would have not only collapsed Denktash's essential networks but it could also cause him to be tried on the grounds of corruption and profiteering, among others. Third, Denktash depended on the support of the Turkish government and military perpetuating his power. The support was given to protect Turkish military interests by helping Denktash in perpetuating the conflict. However, the shift of Turkish priorities towards economic interests that could be better fulfilled through increase cooperation with the EU or a potential membership in that Union undermined his support. Therefore, Denktash belligerently declared that he would not want the Turkish Cypriot community to pursue a pyrrhic peace-despite the domestic political will pointing to the opposite.

Despite Denktash's best attempts, however, the peace talks continued with significant support from Turkey, the EU, and the UN-the last of whom, under the leadership of Kofi Annan, thought that the conflict was ripe for resolution (Bucik, 2012). At the same time, CSOs, labor unions, and student activists started spearheading large-scale demonstrations for peacebuilding and against the authoritarian and corrupt Turkish Cypriot leadership ("An Assesment of Civil Society in Cyprus: A Map for the Future," 2005; Panov and Varon, 2017; Lonnqvist, 2008; Ladini, 2009). Furthermore, these activists started promoting bi-communal trust-building efforts across the border with the RoC ("Building Trust: Civil Society, Trade and Cooperation in Cyprus,” 2011; “An Assesment of Civil Society in Cyprus: A Map for the Future," 2005; Panov and Varon, 2017). Having perceived the germination of significant political will and support for the peace talks within the Turkish Cypriot community, the opposition political parties-which had only won one election in the 20 years since the establishment of the TRNC-decided to mobilize in support of the ongoing movements. No longer able to either pay the activists off or mobilize the military and the police (both of whom report to the Turkish Army and not the Turkish Cypriot legislature) against the movement due to increased international scrutiny, Denktash would make one last gamble in 2003 by unilaterally reopening transit routes between the North and the South of the island as a goodwill gesture which would demobilize a portion of the movement. However, the gamble came off as a sign of weakness and as a last-ditch struggle from an outdated authoritarian leader. Therefore, not only would the opposition parties go on to win the elections, but they would also force Denktash off of the seat of the president.

Displacing the established authoritarian leader was achieved through several significant steps. Firstly, the opposition parties co-opted significant portions of the pro-peace movement in order to increase their base of support. Secondly, the opposition parties had to make several significant promises, the fulfillment of some of which was not actually in their own hands. Importantly, these promises included fighting against corruption as well as increase trade with the EU regardless of whether a peace deal could be struck, in return for eliciting enough support for democratization and peace end in acknowledgement off Turkish Cypriot efforts at reconciliation (Hannay, 2009; Jarraud, 2013). Thirdly, the opposition parties had to show support for the repatriation of tens of thousands of Turkish citizens who settled on the island (mostly in Greek Cypriot properties) after 1974. All of this would combine to undermine democratization in the longer term.

After the opposition parties took political power in North Cyprus, not only did they fail to enact any anti-corruption reforms, but they also started partaking in these age-old traditions of Cypriot politics (Ozadam, 2014; Gultasli n.d.; Beyoglu, 2013; Yusuf, 2013). In fact, one of the most famous leaders of the previous anti-authoritarian movement, Ferdi Soyer, was proven to have embezzled millions of dollars of taxpayer money (Garabli, 2015). As such, many participants of the democratization movement felt betrayed by the elite from the opposition parties. Indeed, as the political culture remained unchanged, the previous selection only served as a circulation of the elite rather than a much-needed political reformation and revision. Moreover, the new elite had co-opted many of the heads of the pro-democracy movement, including the leaders of labor unions. Therefore, the pro-democracy movement swiftly lost steam and started demobilizing after the opposition obtained power; as such, the civil society was no longer capable of serving as of watchdog to enforce accountability unto the political elite.

Concurrently, the EU ceased working as a catalyst for prodemocracy change-in fact, its role became exactly the opposite (Hannay, 2009). Indeed, some of the political leaders of the EU had promised the Turkish Cypriot community rewards for their pro-peace politics such as increased opportunities for trade as well as more financial aid regardless of the final results of the peace negotiations. However, not only was the RoC-whose citizens voted against the Annan (Peace) Plan, thus causing the plan's failure-admitted unilaterally into the Union, but the RoC also started blocking the European overtures towards the Turkish Cypriot community. As such, the Turkish Cypriots felt isolated from and betrayed by the international community. This allowed the hyper-nationalistic parties to argue that none but Turkey could be trusted, and as such further cooperation and integration with Turkey in return for aid would be preferable. Additionally, because some member states of the EU started openly signaling that they would never approve of Turkish membership into the Union, Turkey began to veer away from pursuing EU membership and re-engaged its traditional approach to the Cypriot conflict: maintaining the status quo in order to utilize Cyprus as a military base as well as a space for casino tourism (where many hotels and casinos are Turkishowned (Arasli et al., 2006)). Therefore, Turkey heavily supported the newly-resurgent nationalist parties.

In the meantime, the demonization of the Turkish settlers in the North during the election cycle started causing a heavy escalation of intra-community tensions (Ulas, 2012). Consequently, a nativist movement as well as a pro-Turkish immigrant movement were engendered, which started to divide the society along ethno-national lines. The nativist movement specifically morphed the pro peace and prodemocracy movements into exclusionary and extremist ones: a wish to build a democratic system only for those who were "real Cypriots" (Ulas, 2012; Gazeddakibris, 2019). The left-leaning 
Turkish Cypriot political parties therefore came to be divided among themselves: an extremist nativist wing, a center-left wing, and one that still retained its pro-democracy and pro-peace bend. This heavily undermined the prospects of retaining power for the new elite. Meanwhile, right-wing political parties came together on the platform of supporting the pro-immigrant movement, reemphasizing the ethnic ties with the Motherland (Turkey), and decrying the hypocrisy and corruption of the left-wing parties. This counter-movement, together with the minimum support always provided for right-wing political parties in conflict-ridden contexts, allowed for the right-wing to rally troops in unprecedented rates.

Ultimately, the failure of the opposing political elites to deliver the pro-democracy and anti-corruption reforms that they had promised, the unwillingness and inability of the international community to create crucial bridges to engage with the Turkish Cypriot community, and the ethno-nationalist rhetoric utilized by the pro-democracy movement worked together to create a path for the resurgence of hyper-nationalism. In fact, the nationalist parties emerged from their defeat stronger than ever, dominating the elections (with one party, the UBP, assuming power alone-a rare feat in a parliamentary system) and subsequently reinforcing traditional political practices such as overt corruption. Furthermore, these nationalist parties would also start to increasingly sell land to Turkish companies, in addition to providing Turkish-owned businesses with unimaginable tax breaks. As a consequence, North Cyprus became inextricably dependent on Turkey for its economic survival, which the Turkish Government has since used to 'give directions' for Turkish Cypriot domestic politics. Another two disconcerting practices have been the granting of citizenship to Turkish immigrants wholesale and extra-legally, as well as allowing Turkish citizens to travel to North Cyprus without passports. As a result, North Cypriot democracy was undermined at its core by the co-opted and corrupted prodemocracy movement, despite an electoral win for the elites propped up by the movement.

Currently, North Cyprus possesses a robust civil society scene whose backbone was built during the time of EU and UN engagement. In fact, much of the funding for these organizations still comes from these international organizations. Nevertheless, these CSOs do not possess much political influence and instead advocate for societal change, such as an increase in LGBTQ rights (Kamenou et al., 2019) - which are important and could help foster democratic capacity in the long-term, but do not much affect democratization in the shorterterm. Moreover, these CSOs often cooperate with their Greek Cypriot counterparts, whereby maintaining some intercommunal linkages.

However, the pro-democracy movement is now disorganized and leaderless, and it mainly engages in symbolic protests. Turkish Cypriot's dependence on Turkey has made democratization nigh impossible, and there have been multiple marches organized in protest-to no palpable effect (Gercek, 2012; Ayberk et al., 2019; Gazeddakibris, 2019). Moreover, as the Turkish democracy started declining in quality, through a process called tutelary democratization, the Turkish Cypriot democracy followed suit (Kanol, 2014). While Turkish Cypriots often engage in demonstrations (which is the main form of activism engaged there but, due to a lack of forethought, vision, and organization, it is often weak) against Turkish interference and while they call for Cypriotism, they tend to dissipate soon without substantial results. Cypriotism, specifically, has been contentious: many still identify themselves as Turkish or Greek Cypriots due to the unresolved after-effects of the ethno-nationalist war over and within Cyprus. This has further widened the rifts among the civil society regarding a vision of eventual democracy and Turkish Cypriot polity. The amount of property privatized or simply sold for Turkish citizen's use, in addition to the increase in mosques per Turkey's demand and against Turkish Cypriot protests (Turkish Cypriots are notably irreligious), point to just how much democratization has been curtailed in North Cyprus (Gazeddakibris, 2019).

Ultimately, what can be learned from the case of North Cyprus? Firstly, autocratic regimes in unrecognized states can be quite stable as long as its supporting patronage networks are economically viable. Furthermore, if political leader's claims to power are supported by a hero narrative, potentially due to an armed conflict preceding the state's independence, this stability can be further reinforced. Importantly, while systemic shocks such as economic crises can undermine the aforementioned stability, this only applies in cases where the capacity (within or based on an external sponsor's help) of the existing regime is not enough to absorb this particular shock-or if the regime's repressive capacity is not enough to overcome the shock. Moreover, increased positive international engagement with unrecognized states in democracy promotion can be influential and successful so long as it is empowering towards the locals (i.e. not imposed top-down). Meanwhile, isolation from the international community's scrutiny, as well as negative relations with the international community, appear to reinforce authoritarianism in unrecognized states-due, potentially, to a lack of the Boomerang Effect (Keck and Sikkink, 2014)—and hyper-nationalism-due mostly to increased reliance on the nation as a source of security as promoted by increasingly perceived isolation and threats from the surrounding community, including the parent state. Additionally, the case also points to a tentatively more generalizable lesson: it seems that pro-democracy movements should make alliances with opposition parties to succeed and yet they must also avoid co-optation by the very same parties if they are to successfully promote democracy, rather than just win elections for the latter, in the longer term. The idea of tutelary democracy in unrecognized states is also supported by the Northern Cypriot case as suggested by Kanol (2014), where the covariance between TRNC's and Turkish Republic's quality of democracy is noteworthy. Last but not least, and again this is a tentatively more generalizable lesson as suggested by Smooha (2010; see also Caspersen 2011b), a true pro-democracy movement should avoid making politics only democratic for a certain ethnicity; in fact, deepening ethnonationalist divisions within one's own society appears to be a recipe for disaster with regards to democratization. In such a case, the resulting state would be a type of limited-democracy: an 
ethnocracy (Yiftachel, Oren, and Professor Department of Geography and Environmental Development Oren Yiftachel, 2006) where the tyranny of the majority reigns supreme. Now, despite a strong pro-democratic movement in the early 2000s, the TRNC is teetering among an autocracy, an ethnocracy per Turkish tutelage (Azgin, 2012), and the idea of democracy.

\section{Abkhaz Revolution and Ethnocratization}

Abkhazia is a partially recognized statelet in the Caucasus region that seceded unilaterally from Georgia through an extra-legal public referendum in 1999, where its citizens seemingly-despite the disputes regarding whether it was freely or fairly-voted for independent statehood. Prior to the final act of state independence in 1999, however, Abkhazia declared sovereignty in 1990 ( 1 year before Georgia likewise declared its own sovereignty over all of the territories now controlled by Georgians, Abkhazians, and South Ossetians) and again in 1992, after the dissolution of the USSR. Between 1990 and 1992, the border issues remained mostly as a legal battle, yet the tensions over the questions of sovereignty and autonomy escalated. This eventually ended up resulting in the War in Abkhazia in 1992-93. Abkhaz forces, led by Vladislav Ardzinba, would win the war and thus de facto sovereignty over the Abkhaz territories, while the war also caused about 30,000 casualties from all sides and the displacement of 250,000 ethnic Georgians from Abkhazia's lands.

The initial state of democracy in Abkhazia was questionable at best, as the 2002 elections saw the withdrawal of opposition groups in protest of pre-election manipulations by the regime (Bakke et al., 2014; Kopeček et al., 2016). Such manipulation was especially evident in the frequent dissemination of progovernment propaganda through the state-controlled media organizations (Bakke et al., 2014; Kopeček et al., 2016). Moreover, the first President of Abkhazia, Ardzinba, who was first inaugurated in 1994, retained his presidency through elections where he ran as the sole candidate. Meanwhile, Abkhazia became heavily dependent on Russia for economic and military aid whereas Russia also supported the chokehold that Ardzinba maintained on political power due to the latter's support for the former's agenda with regards to controlling Abkhaz lands due to strategic concerns.

2004 proved to be a year of political change in Abkhazia as Ardzinba had to resign due to health concerns. Interestingly, the candidates supported by Russian president Vladimir Putin as well as ex-President Ardzinba would fail to win the election, losing to the opposition candidate Sergei Bagapsh. The new government faced Russian pressure to include Russia-friendly politicians in the cabinet and had to cave in due to the aforementioned level of Abkhaz dependence on Russia for economic and military survival (Kopeček et al., 2016).

Nevertheless, the elections of 2004 could be marked as the beginning of the process of democratization in Abkhazia (Kopeček et al., 2016)-although the progress would not be neither smooth nor linear. The chance displacement of the authoritarian leader weakened some of the patronage networks and encouraged free media and civil society to emerge. Indeed, CSOs became more commonplace and were strengthened during this time (Mikhelidze and Pirozzi, 2008). Moreover, independent media organizations, primarily sustained by financial assistance from their western counterparts, started supporting prodemocracy protests. However, Western politics mainly supported Georgian autonomy and territorial integrity, whereas the Abkhaz CSOs and media organizations promoted Abkhaz independence and self-determination. Due to these disagreements and differences of vision over the GeorgiaAbkhazia conflict as well as the politics involved, the funds from the West would dry up (Kopeček et al., 2016). As such, independent media never quite lived up to its potential as a democratizing factor, and the CSOs failed to grow enough capacity to influence Abkhaz politics.

There was no particularly organized pro-democracy movement that promoted democratization observed in Abkhazia during this era of democratization (2002-2014). Instead, the apparent corruption of the political elite, who continued to live luxuriously despite a decline in socioeconomic prosperity in the country at large, started undermining the chokehold that the authoritarian government had on power. In fact, the organization of veterans from the war for independence started denouncing President Ardzinba and his cadre of allies, whose hero image had previously allowed them to remain untouchable and to continue ruling in an authoritarian fashion (Kopeček et al., 2016). This anti-corruption movement translated into an anti-authoritarian movement, which then promoted democratization.

A secondary factor that strengthened the Abkhaz bid for democratization was the state's inability to respond to and to suppress protests and opposition movements; the state's weakness created an opportunity window for socio-political change. Thirdly, the movement towards democracy was also helped by the emerging principle of earned sovereignty: the idea that an unrecognized state could obtain a measure of recognition by the international community-with which it would also obtain opportunities for trade and increased aid-by demonstrating a standard for respect for human rights, civil liberties, and political rights (Williams, 2002; Williams et al., 2002; Caspersen, 2011a). This idea of increased political rights that would also lead towards economic prosperity promoted widespread support for democratization among the public in Abkhazia.

Russia eventually recognized Abkhazia in 2008 and started to further integrate its military and economy to Russian interests and systems through conditional provision of aid. Despite increased Russian involvement, the 2011 presidential elections as well as the 2012 parliamentary elections were largely democratic, free, and fair, demonstrating an increase in the democratic capacity in this unrecognized state. The 2008 recognition and the subsequent democratic elections were products of the Abkhaz and Russian hopes to replicate the Kosovar model of "earned recognition". However, the international community would not invoke the same standards for Abkhazia as it did for Kosovo, which would eventually hamper democratization.

Unfortunately, due mainly to the chosen traumas of the War in Abkhazia as well as the perceived external threats to Abkhaz 
independence, an ethno-nationalist trend towards the apportioning of political rights started emerging in Abkhazia. This is the context in which the Abkhaz Revolution of 2014 occurred. Interestingly, this Abkhaz revolution-supposedly proAbkhaz "purity" - was anti-Georgian yet somewhat pro-Russian (Beachain, 2014; Lomsadze, 2014). It was driven by a lack of economic reforms and prosperity as well as ethnic Georgians being granted citizenship by the Ankvab government in addition to a supposed misappropriation of Russian aid (and a lack of movement towards further integration with Russia). On May 27, 2014, protesters/revolutionaries stormed the Office of the President, whereby Ankvab fled the capital Sukhumi, eventually resigning after decrying the revolution as a coup d'état in disguise.

The elections of 2014 therefore featured the suppression of the right to vote for ethnic Georgians living in Gali District. Moreover, Abkhaz diasporas in Turkey and Russia got their own polling stations to vote in this election, despite a considerable chunk of the local residents being denied similar access to voting rights. This suppression of votes based on ethnicity allowed for an ethno-nationalist and authoritarian leader, Khadjimba, to win the presidency by a very small margin. The elections were not free or fair as violence was frequently utilized together with voter suppression in order to secure the win for Khadjimba (Kopeček et al., 2016). Khadjimba had been a favorite of Moscow for a long time and had been advocating for increased cooperation and integration with Russia-a stance that gained popularity as the hopes for earned recognition and international integration faded.

We can claim, therefore, that the hopes for an international rapprochement-especially if it would mean increased economic opportunities-had initially been an important factor for the onset of the pro-democratization movement in this unrecognized state. However, without an international reciprocation of the Abkhaz aspirations, this "democratization for recognition" ideology-and the accompanying pro-democracy momentum - fell apart. Subsequently, authoritarianism made a resurgence, as the trauma of the war in Abkhazia drove identitybuilding in the absence of external guarantees for security. This is quite similar with the case of Cyprus.

Also important is the fact that, based on this case, we can tentatively surmise that not all pro-democracy movements are positive ipso facto. Indeed, in the case of Abkhazia, the 2014 Revolution, while outwardly democratic or at least antiauthoritarian, was only democratic for those who qualified (according to the movement leaders) as "true Abkhazians"-where being Abkhazian was defined along ethnic lines. Interestingly, this ethno-nationalist exclusion did not apply to Russians-demonstrating the political nature of identity-building as well as the granting and defending of rights in spaces where populism and/or nationalism reigns supreme.

Currently, Abkhazia is a nominally-independent unrecognized ethnocracy that is heavily dependent on Russia for its economy. Russia, in the meantime, maintains a relatively large military presence in Abkhazia, for "defending the latter's independence against Georgia”. Abkhaz elections teeter between authoritarian and pro-Russian incumbents and independents gaining power, but the pro-democracy and reform left-wing has been heavily damaged by failures of democratization to promote economic growth and prosperity.

In the meantime, while Abkhaz elections are competitive and pluralistic with a good structure to promote freedom of choice, they still do not allow for ethnic-Georgians living in Abkhazia to vote unless they have obtained Abkhaz citizenship by forsaking citizenship in Georgia. Importantly, the government and elected officials cannot independently make policies, especially under the 2014 Russian-Abkhaz Treaty, which has made Abkhazia so dependent as to be considered a puppet state (Pugliese, 2015). However, and despite opposition challenges to the process of assimilation, the democratization process has been stalled due to the level of dependence on and interference from Russia. Most of the media outlets are also still controlled by the government and Russian broadcasts are widely disseminated. Additionally, the Georgian Orthodox Church faces a level of discrimination. In fact, the "pro-democracy" revolution of 2014 underlined the important of letting the Abkhaz will and independence be preserved in a purified fashion-i.e., against Georgian influence (Kopeček et al., 2016)-further reinforcing the ethnocratic status of Abkhaz governance.

It is also important to note, however, that there is a reluctance on the part of Abkhaz government in allowing Russians to buy large chunks of Abkhaz land. Potentially, Abkhazia knows that the Russian recognition of their independent nationhood as well as the geostrategic value of Abkhazia allows them to fight against a complete subsuming and folding of Abkhaz identity into a Russian one as a minority. Nevertheless, the facts on the ground remain that Russia's influence over Abkhazia is large enough to the point of locating the de facto sovereignty over the territories in Moscow rather than Sukhumi. It appears to many experts that Abkhazia may be slowly but assuredly getting assimilated into Russia. Ultimately, Abkhaz identity and sovereign statehood remain because Russia has yet to make aid conditional on concessions from either due to larger geostrategic interests.

\section{Taiwan's Rapid Democratization}

Taiwan, also known as the self-declared Republic of China (ROC), is a partially-recognized and relatively small islandstate. Taiwanese territories were ceded by China to Japan at the conclusion of the First Sino-Japanese War in 1895 and were colonized by the latter. Subsequently, China regained the territories at the conclusion of World War II in 1945 as Japan and her allies surrendered. As such, the Taiwanese were hoping to have been liberated from being second-class citizens under Japanese rule and reuniting with their kin group as equals.

Meanwhile, mainland China, which had been under the rule of the Kuomintang (KMT) Party and the nationalist wing ever since the displacement of the Qing Dynasty and the establishment of the ROC, was experiencing several troubles and significant political changes. The KMT, led by General Chiang Kai-Shek, had initially align itself with the Communist Party of China (CPC) in order to earn Soviet support. However, they rapidly betrayed and purged the communists from the ranks of power holders lest communist principles did not fit with their nationalist 
values. As a result, the $\mathrm{CPC}$ and other powerful actors such as the warlords ousted by the KMT forged an alliance in order to remove the KMT from power. This initiated the Chinese Civil War, which would be waged intermittently from 1927 to 1949. Indeed, while the KMT and the CPC would briefly reconcile and form the Second United Front to stave off the Japanese invasion that occurred during the Second Sino-Japanese War, the alliance would only last from 1937 to 1941 . The last and the most violent phase of the civil war would occur between 1945 and 1949, where the CPC led by Mao Zedong would dominate, eventually pushing the KMT to retreat from the mainland and into Taiwan.

In the end, the CPC declared the People's Republic of China (PRC) - a one-party state with a communist system - which claimed sovereignty over all of the Chinese territories. However, the KMT re-established the ROC in Taiwan and declared itself the rightful sovereign of all Chinese territories-a claim that would be recognized by much of the international community (especially the United States) until 1971 to deter the outwards spread of communism from China. Since the ROC was seen as an essential bulwark against communist expansionism, it was provided with unconditional support from the West until mid-1980s (H. Lin, 2016).

During this era of unconditional support, the KMT ruled Taiwan in an authoritarian fashion under the militarized leadership of Kai-Shek (H. Lin, 2016). In fact, when the mainlander KMT party arrived in Taiwan, they quickly excluded and ostracized the native population of the island whom they believed to have been influenced too much by Japan (Wang, 1992). Moreover, the KMT had just lost a civil war against the Communist Party, whereby the party's threat perception of a potential communist revolution-whereas they believed communism was a fast-spreading virus-was exceptionally high (Wang, 1992). Therefore, the KMT immediately declared martial law with the rhetorical reasoning of curbing communist dissent but with the actual result of eliminating political opposition and excluding native Taiwanese from political power (Blundell, 2012). Indeed, when the Taiwanese population inevitably rose up in protest against the iron-fisted rule of the KMT in December 1949, the latter would label the pro-democracy protesters as communist agitators and duly mobilized its armed forces against them. This event, called the Kaohsiung Incident, resulted in thousands of deaths, injuries, and arrests. Such heavy-handed repression would galvanize Taiwanese activism yet at the same time push Taiwanese political activists to operate underground until an opportunity window emerged, which would prove elusive for another three decades. Importantly, the KMT experienced no international fallout from this incident due to Taiwan's strategic importance for the West-supposed champions of democracy and human rights-in the context of the Cold War. Clearly, both democracy and human rights promotion are political in nature and only selectively applied. In fact, the American support for Taiwan remain quite the same and there was a lack of political will to scrutinize Taiwanese internal affairs to retain an anti-communist partnership (Hsiao-ting Lin, 2016). This constant support from the international community at large and from the United States in particular, together with both the KMT's capacity and willingness to use repressive tactics and the KMT's chokehold on the local economy, allowed for authoritarian stability for decades to come.

Overall, authoritarian stability in Taiwan was largely based on external support as well as a virtual monopoly over the economic institutions of the island. Therefore, a natural consequence of the gradual loss of Taiwan's strategic importance was that the capacity of the authoritarian regime to weather troubles-such as economic underperformance, international human rights standards, and domestic political opposition-started being undermined. Indeed, beginning with 1971, the PRC started garnering recognition as the sole sovereign of all of China in international circles-which equaled a gradual loss of recognition for and the subsequent decline of ROC'S diplomatic rights and power. Slowly, the international community shifted from supporting any anti-communist regime unconditionally towards demanding the respect for human rights and democracy in return for their aid, increasingly isolating Taiwan. Importantly, the international community did not isolate Taiwan economically despite its withdrawal of recognition vis-à-vis Taiwanese sovereignty. In fact, aside from providing aid, Taiwan also relies on the international community for trade. These two economic bridges between the international community and Taiwan have allowed the former to exert influence and pressure on the latter regarding democratization and human rights.

This shift in international priorities and attitudes, together with increased international scrutiny as well as a growing subsuming of economic power by the native Taiwanese population, prepared the necessary conditions for a prodemocracy movement. Moreover, the war hero/dictator and the main enforcer of martial law, General Chiang Kai-shek, died in 1975, undermining authoritarian stability-especially as the potential successors for political power started vying and dividing among themselves. In light of this favorable turn in conditions, the opposition, eventually united under the banner of Tangwai, started promoting political gatherings and protests (Meseznikov, 2013). Nevertheless, the KMT only responded in a limited fashion due to a decline in their authoritarian power; therefore, the opposition sensed the opportunity to escalate the conflict, which led to the Gushan Incident of 1979.

In this case, the KMT once again mobilized its armed forces in order to suppress the movement, leading to such tragedies as the massacre of the Lin family, where Lin Yi-hsiung was the leader of the pro-democracy movement. Unlike in 1949 however, the arrests and imprisonment as well as the corrupt behavior of the police caused international backlash-including a legislative scrutiny regarding whether the U.S. should continue to provide aid to Taiwan. This was a death knell for the authoritarian regime, as the U.S. had become the sponsor state for Taiwan, without whose military and diplomatic aid Taiwan's independence, economic, and political survival could not be guaranteed. As a result, the KMT had to softened its political approach and allow for political opposition to emerge for the sake of demonstrating progress towards the prerequisite democratization and to imply an attempt at responding to international human rights 
standards. These changes in KMT's approach would subsequently lead to the rise of the main opposition party-the DPP (the Democratic Progressive Party). The DPP would start arguing for Taiwanese independence and selfdetermination-which would promote democratization.

KMT could no longer dam the flood of changes-democratization became inevitable due to internal and external pressures. From 1980 to 1985, Taiwan would slowly enact democratic reforms while the KMT began to accept and promote more native Taiwanese members among its ranks in order to perpetuate its hold on political power. These changes would eventually lead to a native Taiwanese member of the KMT, Lee Teng-hui, to assume power in 1988. However, the change in the elite did not necessarily promote the rates or the breadth of Taiwanese democratization.

Indeed, traditional power holders appear to be dragging their feet, despite the revocation of martial law in 1989. The unelected and authoritarian nature of the Taiwanese National Assembly, where most members were appointed for life and in turn decided on the president and the prime minister, was especially problematic with regards to Taiwanese democracy. As a result of the slow pace and limited impact of democratic reforms, the pro-democracy Wild Lily Movement began on March 16, 1990. The movement was spearheaded mainly by student leaders from the National Taiwan University and employed tactics such as sitins and fasting. Additionally, the DPP and the Progressive Women's Union also supported the movement as allies. One of the largest goals tackled by the movement was the dissolution of the undemocratic and authoritarian-leaning National Assembly.

The White Lily Movement garnered the support of thousands, successfully remaining non-violent by dissolving in about 6 days when participation went out of hand, consequently increasing the potential for tactical deviations into violence. The movement created an opportunity for president Lee, who would be the first popularly elected president of Taiwan in 1996, to enact more radical reforms (Wang, 1992; Huang, 1998; Jacobs and Ben Liu, 2007). The Wild Lily Movement itself is accredited with speeding up the democratization process in Taiwan, where president Lee started transferring legislative power to a fully and democratically elected body, eventually dissolving the National Assembly in 2005 in favor of the Legislative Yuan.

Following its success, most of the leaders of the Wild Lily Movement would eventually be co-opted by the DPP and join traditional institutional politics. Therefore, the civil society of Taiwan would lose strength and momentum with regards to activism. Indeed, the Wild Strawberry Movement of 2008, which was inspired by its predecessor of 1990 and pursued increased rights to assemble and protest peacefully, is largely considered to have failed due to a lack of organizational and tactical know-how. Nevertheless, both the political repression of the martial law era and the success of the Wild Lily Movement clearly created a culture of political activism in Taiwan. This has also been evident in the fact that many likewise-inspired pro-democracy movements have occurred since the Wild Lily Movement to varying degrees of success.
Importantly, this culture was quite evident during the sunflower movement in 2014, which was led mostly by youth in protest of the KMT-dominated government's attempts to sign a Free Trade Agreement with China. This was a pro-democracy movement when considering the fact that China had-and has-been attempting to interfere in and influence domestic decision-making in Taiwan. Additionally, the movement was spurred on by a surging sense of indigenous nationalism end economic marginalization of highly educated Taiwanese youth at large (Ho, 2018). In this movement, the activists ended up seizing and occupying the legislative building. The KMT's failure to effectively deal with the protests, in addition to the evidence of popular support against the trade deal with China, ended up prompting a resurgence of the DPP in the following elections as well as the trade deal to not be ratified in the legislature-despite executive signature. Nevertheless, the movement only remained active in 2014, whereas many of the activists were co-opted into the ranks of the DPP, causing the movement to rapidly demobilize. Additionally, the fact that the government did not concede to the movement demonstrated the power of institutional politics in Taiwan (Ho, 2018). Subsequently, this unresponsiveness caused frustration and disillusionment among the activists, many of whom eventually demobilized and started prioritizing private concerns over social change (Ho, 2018). Meanwhile, some new organizations for democracy, social justice, and Taiwanese identity emerged from the movement as well (Ho, 2018). However, aside from a circulation of the elite, the only considerable successes of the movement were: phasing out of nuclear power (which the Taiwanese activists had been working on for around two decades) and the reform of high school curricula. Therefore, the movement was mostly successful in the social sphere and not as much in the political sphere, which likely caused the politically-minded activists associated with the movement to switch from extrainstitutional activism to political party participation.

Taiwanese politics has been charged and divided by hypernationalism due to the ongoing conflict with the PRC (Diamond, 2001; Chu, 1996; T.; Lin, 2005). However, in this case, the Taiwanese identity has been decoupled from ethnicity and instead emphasizes national independence and pride, rather than the ethnic purity of the group. In fact, Taiwanese nationalism is inclusive of all who feel some belonging to the island-whether one is ethnically a mainlander or a native alike. Therefore, the quality of the democracy in Taiwan did not decline due to a surge of nationalism, unlike in other cases. This shows that nationalism does not need to lead to authoritarianism or ethnocratization; the nature of identity-building-i.e. whether the end product is inclusive/diverse or exclusive-matters more visà-vis the identity's effects on democratization, at least in unrecognized states.

The case of Taiwan is a great example of the power and impact of the international community in supporting the emergence and success of pro-democracy movements in unrecognized states. Indeed, the differences between the movements of 1949 and 1979 clearly demonstrate that the international community, by making aid and trade conditional on the fulfillment of democratic and human rights norms as well as by increasing scrutiny over the 
domestic politics of de facto states, can create the conditions for successful socio-political activism. As such, we can also conclude that the international community needs to sustain engagement with unrecognized states, regardless of their status in the international realm, if pro-democracy movements are to succeed in these spaces.

Another lesson from Taiwan is that institutional politics are clearly too powerful and too alluring for those who want to make political change in unrecognized states-which can sometimes undermine the momentum and sustainability of pro-democracy movements. Indeed, in these spaces, political powerholders dominate economic possibilities, receive and distribute aid, and make decisions on local identity, education, and land distribution, which are components that determine the direction of the existential conflict between parent and unrecognized state, raising the stakes involved. Most of the activist leaders of the movements from 1990 to 2014 made a swift switch into party politics. While this is not ipso facto problematic vis-à-vis democratization, the quality of a democracy is harder to safeguard without extra-institutional watch dogs and accountability. On the one hand, from a pessimistic point of view, citizen activism is an essential ingredient of a good democracy, which makes the fact that activists leaders are often co-opted by opposition parties disconcerting. On the other hand, from an optimistic point of view, activist's ability to transition into traditional politics demonstrates an openness for accepting social change within established political institutions in Taiwan. All in all, the case of Taiwan demonstrates the centrality of international scrutiny and support in the onset and initial success of pro-democracy movements in unrecognized states, as well as the fact that movements for social change set a good precedent for further activism within societies.

\section{ANALYSIS AND LESSONS LEARNED}

Ultimately, what do the cases of North Cyprus, Abkhazia, and Taiwan reveal about pro-democracy social movement onset, success/failure, and sustainability in unrecognized states? And what might be some more generalizable dynamics here? There are multiple lessons gleaned throughout these three cases regarding: the roles of external actors such as the international community and sponsor states; the roles of authoritarian stability and opposition parties; the centrality of the economy; the importance of the movement's thrust and capabilities; and the impact of a history of ethno-national conflicts. For the purposes of this section, each of these factors will be elaborated on.

To begin with, external actors appear to play a central role in the onset, success, and sustainability of pro-democracy movements in unrecognized states. On the one hand, in all three cases, a lack of international scrutiny and engagement were common contributors to authoritarian stability. On the other hand, again in all three cases, the requirement of increased democratization and increased provision of human rights in return for international recognition, increased aid, and a boost in trade were common drivers towards pro-democracy movement's onset and success as these created the prerequisite political opportunities. The caveat here is that the promises associated with democratization need to be followed through if the movement's momentum and success are to be preserved. Indeed, in the case of Taiwan, ensuring a level of engagement (even if not recognition) as well as trade and aid allowed for rapid and sustainable democratization, whereas in the cases of North Cyprus and Abkhazia, the lack of international response to democratization and the perception of broken promises eventually drove these two states towards ethnocratization, increasingly authoritarian politics, and extreme levels of dependence on the sponsor state (Ulas, 2017). This brings us back to the idea of framing: in unrecognized states and potentially other internationally-isolated states, the hope and belief that the movement and its success in promoting democratization matters and will bring prosperity and status must be maintained for longterm stability and success.

It is also essential to underline that the shift in the international community's overt priorities (especially in the West), from ideological warfare and related support to upholding democratic and human rights standards, has also been vital for the onset and success of pro-democracy movements in these three cases. In fact, some pro-democracy movements in unrecognized states, such as in the cases of Abkhazia and North Cyprus, only garnered momentum due to the idea of obtaining international engagement, if not recognition, through enacting democratic reforms. Meanwhile, in the case of Taiwan, aid conditionality naturally undermined authoritarianism while promoting democratization. Clearly, the international community and its political priorities have an immense role to play in the onset and success of prodemocracy movements in unrecognized states, especially when they are authoritarian-leaning. From these factors, we can glean that international context and framing regarding the movement's goals, such as democratization, matters for galvanizing support for the movement and to create the political opportunities by undermining authoritarian state power in unrecognized states. As such, we can also argue that a friendly contextual framing and culture might precede and in turn be prerequisites for the appearance of political opportunity structures in these cases.

The role of the sponsor states in each of the three cases studied herein cannot be overstated. To begin with, all three cases conform to the idea of tutelary democratization (Kanol, 2014) - that is, the idea that dependent/sponsored states will tend to replicate the quality of democracy of their sponsor state. The Abkhaz regime reflects the widely corrupt and limitedly democratic nature of Russian governance; the Northern Cypriot regime, much as the case of Turkey, is an ethnocratic and limitedly-democratic republic; Taiwanese democracy replicates the strong human rights record and institutional depth of the American regime. Partially, this might be in response to the fact that aid from the sponsor states is conditional towards certain reforms to the domestic regime. As such, sponsor states clearly intervene in or at least influence-for better or worse-the domestic affairs of states dependent on them, which could be considered anti-democratic as this is an external influence over indigenous political will. Here, 
it is also important to recognize that pro-democracy movements will not be guaranteed international support a priori regardless of regime violence or non-violence being adopted by the movement as political considerations around unrecognized states appear to reign supreme, unlike what has been argued recently regarding the success of anti-authoritarian civil resistance at large (Chenoweth and Stephan, 2012). Instead, in cases such as authoritarian Taiwan, "grand strategic" or security concerns or, as in the cases of Abkhazia and North Cyprus, concerns regarding regional power balances, alliances, and stability may dominate motives of engagement/non-engagement.

In the domestic arena of unrecognized states, authoritarian stability and the opposition's stance appears important for prodemocracy movement's onset, success, and sustainability as predicted in the literature. Authoritarian regimes in unrecognized states prove quite stable when they can establish and maintain widespread patronage networks, usually by gifting land and property or by providing government jobs. The bloated government sector, however, usually implodes, undermining authoritarian stability (Isachenko, 2012). Authoritarian stability also depends on the regime's capability of repressing opposition movements. All three cases considered in this paper indicate that, insofar as an unrecognized state's regime is capable of 1) overcoming systemic shocks such as economic crises through fiscal incentives and injections; and 2) mobilizing armed forces to legitimately and effectively repress any prodemocracy or anti-authoritarian movements, then the regime can preserve stability. Additionally, the cases indicate that if a state has recently emerged from a fight for independence and a war hero has taken power, the newly-minted authoritarian leader appears to possess a measure of invulnerability until they fail to maintain patronage networks (Abkhazia); a new, younger generation of activists who do not unconditionally support the leader emerges (North Cyprus); or the leader is abandoned by external allies (Taiwan). Having all of these factors present explains the authoritarian stability and the lack of political opportunities for movement emergence and success that followed the establishment of all three of the unrecognized states considered for this paper.

The political opposition in unrecognized states, meanwhile, appears to wait for an opportunity window to emerge in order to break into political power, where the onset of pro-democracy movements can indicate such a window. Indeed, in these cases, it is not only the movements but also the power-starved/ opportunistic opposition elite that await such windows, and the elite/movement interests may align only temporarily. In such moments, according to two of the cases considered, the opposition tries to first bandwagon on and then co-opt the prodemocracy movement, demobilizing the latter. This may lead to a decline in the momentum for democratization (North Cyprus), or it may lead to better democratization as in the case of Taiwan, as the opposition's support for Taiwanese independence-a platform through which they garnered votes-was well-served by democratization (as Taiwanese are the majority in the ROC). Clearly, however, opposition partie's support has been essential in unrecognized states for movement's success in affecting politics across the two cases as predicted by the literature; in such cases, and possibly with other authoritarian-leaning contexts, the trick for pro-democracy movements appears to be avoiding cooptation and demobilization per the cases studied.

Economic survival as a motive for power-holding elite appears to be yet another driver of pro-democracy movement's emergence and their success in unrecognized states. Indeed, according to Tilly's studies of European processes of democratization, democracies have historically emerged when the state/power holders are forced to concede civil liberties and political power to their citizens due to a need to extract resources-such as taxes-from the latter for economic survival (Tilly, 1992). In the cases of Abkhazia and North Cyprus, the regime was more dependent on the sponsor states of Russia and Turkey, respectively, than their own citizens for economic survival; hence, they were able and willing to repress pro-democracy movements. Meanwhile, in the case of Taiwan, not only did the sponsor state require democratization starting from 1980s, but the state also depended on native Taiwanese businessmen for economic survival through trade, which led to regime responsiveness towards the pro-democracy movements. Economic underperformance, meanwhile, when coupled with the regime's increasing inability to maintain patronage networks, can create enough domestic political will to mount a pro-democracy struggle while undermining the regime's ability to repress the said movement, thus allowing for movement onset and success in unrecognized states-as in the cases of North Cyprus and Abkhazia. Having alternative hopes for economic prosperity, such as through international engagement, appears to help in these cases. All in all, economic concerns-more so than human rights, civil liberties, or political rights-appear to drive prodemocracy movement onset in unrecognized states by providing political opportunities. As such, in these cases, providing conditional aid and increasing engagement options in addition to sanctions might be a method to aid pro-democracy movements.

The capabilities and nature of the movements themselves are naturally central to the success of pro-democracy movements in unrecognized states-and, tentatively, in other authoritarianleaning contexts. Indeed, as observed in post-2004 movements in North Cyprus and post-1990 movements in Taiwan, prodemocracy movements inspired by the tactics of their successful predecessors may fail due to a lack of understanding regarding the need to organize, build capacity, and engender shared knowledge of and commitment towards direct nonviolent action-as suggested by the literature (Vidwans, 2020). Moreover, if movements are mobilizing around societal issues rather than political ones, they appear unable to engender democratization despite the fact that increased civil liberties are part of a quality democracy. Nevertheless, if we are to take the long view, we can argue that these slow and small successes can change the local political culture/contentious repertoire to eventually lead to larger movement successes. Meanwhile, in post-conflict contexts such as unrecognized states, due to the politicized nature of social activism, most international aid appears directed towards apolitical movements aiming to address societal issues in order to not ruffle any feathers. As such, pro-democracy movements in post-conflict contexts may not be well-supported by the 
international community, thus undermining the potential of such movements in post-conflict contexts.

Last but not least, as we observe in all three cases, due to historical grievances, chosen traumas, or ongoing threats to their independence (perceived or real), unrecognized states that have emerged as a result of recent warfare tend to be driven largely by ethno-nationalistic concerns (Smooha, 2010; Caspersen, 2008; 2011b)_such as in the cases of Abkhazia and North Cyprus. In these cases, "non-suitable minorities" (e.g. Georgians in Abkhazia and Maronites or Turkish immigrants in North Cyprus) may suffer from attempts to exclude them from political processes. As such, cases such as North Cyprus and Abkhazia may at best lead to ethnocratization, which is an undesirable and limited form of democracy that exists only for some (Smooha, 2010; Ulas, 2017). However, all is not lost: the Taiwanese case demonstrates that, when pro-democracy activists can avoid ethnocizing the national identity and instead emphasize diversity, nationalist fervor can lead to democratization. In the case of Taiwan, the movement leader's motivation may have been to avoid antagonizing China into war or to avoid a civil war; regardless, this type of inclusive nation-building worked much better for democratization than the ethnocratic tendencies of the Abkhaz and Northern Cypriot movements. How pro-democracy movement can avoid the ethno-national tendencies brought about by chosen traumas and perceived threats in order to achieve success in democratization, however, is not quite clear from these three cases and needs to be investigated further. Nevertheless, it is important to note that not all pro-democracy movements are desirable-and thus not all movements should be supported ipso facto.

\section{CONCLUSION AND IMPLICATIONS}

To conclude, in cases of unrecognized states governed by an authoritarian-leaning regime, pro-democracy movements may emerge due to a combination of 1) systemic shocks whose severity exceeds the regime's capability of accommodating them, with or without sponsor state support; 2) the international community's well-targeted sanctions, engagement, and promises, although promises need to be kept to ensure the sustainability of prodemocracy); 3) a decline in the regime's repressive capacity due to a decline in the pertinence of the hero narrative and/or an inability to maintain patronage networks, as well as a decline of perceived threat from the parent state or the international community; and 4) sponsor state's willingness to support democratization through tutelary engagement. In all three cases, not only the idea but also the perceived possibility of earned recognition-or at the very least, earned international political and economic engagement-proved central to the emergence, sustainability, and success of the movements. As such, pro-democracy movements in unrecognized states would benefit from a shift in international engagement priorities from a focus on the politics of recognition to a humanitarian emphasis on democratic rights.
On the theoretical end, the findings support the PPT framework which emphasizes political opportunities, formal networks, and framing with the centralization of international engagement and context as core factors. As predicted in the framework, findings also indicate that while the movement onset is largely dependent on factors external to the movement, the movement's sustainability and long-term success will depend on the activist's ability to increase organizational and tactical capacity as well as to leverage alliances with opposition parties while avoiding co-optation.

Given all of this, what are the implications on other cases-i.e. how generalizable are these lessons learned? Considering the small amount of cases studied in an exploratory fashion, any genarlization will need to be tentative. Nevertheless, the lessons learned from these three cases may be applicable to any state that exhibits high levels of dependence on a sponsor state; states that are small in size; states that suffer from differing levels of isolation from the international community; and states that have recently been through violent conflicts revolving around ethno-national identity groups. The implications of these cases are that the international community must not simply isolate or freeze and forget "undesirable states"; rather, international engagement-even without recognition-appears necessary to support democratization. Indeed, the simple act of international scrutiny matters-although the effect may be dependent on international value alignments. On the one hand, prodemocracy movements are reinforced where the international community's values align with human rights, civil liberties, and political rights; on the other hand, when geopolitical interests are more central for international support than democratization, prodemocracy movements may be undermined. Nevertheless, movements tending towards ethnocratization must be either reformed through conditional aid or not supported. On that note, we can also claim that while movements will brand themselves according to what message "sells" - and thus the brand shift from communist/anti-communist to prodemocracy in post-Cold War era,-economic and political incentives and opportunity windows, rather than grievances based on regime type, appear to be the more pertinent drivers of pro-democracy movements.

All in all, pro-democracy movements in unrecognized state contexts may be heavily repressed until an eventual opportunity window can either be created (North Cyprus and Taiwan) or emerges by chance (Abkhazia). Moreover, if movements are to be successful in unrecognized states, the international community must clearly keep prioritizing democratization and human rights as a basis of sovereignty and state legitimacy over other concerns, such as historical claims to territories, in addition to providing economic incentives such as increased trade in return for democratization as a supplement. Additionally, the international community and pro-democracy activists 
must build the capacity to take advantage of these windows and to not allow for authoritarian backlashes due to ethnonationalism and/or lack of international engagement/ scrutiny and positive economic incentives (North Cyprus and Abkhazia). Instead, the Taiwanese model of engagement without recognition must be pursued-as the case clearly demonstrates that pro-democracy movements that are well-supported both internally and externally are bound to succeed regardless of how stable the preceding authoritarian regime(s) may have been.

\section{REFERENCES}

Adamides, C. (2015). "Conflict Perpetuating Routines in the Cypriot Comfortable Problem," in In Resolving Cyprus: New Approaches To Conflict Resolution. Editor J. Ker-Lindsay (London: I.B.Tauris).

Aleman, J. (2015). Protest and Institutional Change. Oxford Handbooks Online. August 6, 2015).

An Assesment of Civil Society in Cyprus: A Map for the Future (2005). "Executive Summary. South Africa, New York, Geneva: Civil Society Assessment. CIVICUS. Available at: http://www.civicus.org/media/CSI_Cyprus_ Executive_Summary.pdf.

Arasli, H., Bavik, A., and Ekiz, E. H. (2006). The Effects of Nepotism on Human Resource Management. Int. J. Soc. Soc. Pol. 26 (7/8), 295-308. doi:10.1108/ 01443330610680399

Ayberk, İ., Akşit, S., and Dayioğlu, A. (2019). Bir De Facto Devlet Olarak Kuzey Kıbrıs'ta Sivil Toplum: Toplumsal Tepki, Kibrıs Türk Sendikaları Ve Türkiye'yle İlişkiler. December: Uluslararası İlișkiler Dergisi, 127-144. doi:10.33458/ uidergisi.653013

Azgin, Bilge. (2012). "The Uneasy Democratization of Turkey's Laic-Ethnocracy." Doctoral Dissertation. Manchester, UK: The University of Manchester. Available at: https://www.escholar.manchester.ac.uk/uk-ac-man-scw.

Bakke, K. M., O'Loughlin, J., Toal, G., and Ward, M. D. (2014). Convincing StateBuilders? Disaggregating Internal Legitimacy in Abkhazia. Int. Stud. Q. 58 (3), 591-607. doi:10.1111/isqu. 12110

Bakker, F. d. H., and Frank, G. A. de. (2016). "Boomerang Politics: How Transnational Stakeholders Impact Multinational Corporations in the Context of Globalization," in A Stakeholder Approach To Corporate Social Responsibility (New York: Routledge).

Beachain, D. O. (2014). What Happens when an Unrecognized Country Experiences a Revolution."IPI Global Observatory Blog.13, 2014.

Bellamy, A. J. (2009). Kosovo and the Advent of Sovereignty as Responsibility. J. Intervention Statebuilding 3 (2), 163-184. doi:10.1080/ 17502970902829952

Berg, Eiki., and Molder, Martin. (2012). "Janus-Faced Human Security Discourse: EU and Russia Talking Past Each Other in Kosovo and the Caucasus." EU-Russia Papers. Tartu, Estonia: Tartu University Press. Available at: http://alleuropalux. org/old/fileserver/2012/67/Janus-Faced-Human-Security-Discourse.pdf.

Berg, E. (2009). Re-Examining Sovereignty Claims in Changing Territorialities: Reflections from 'Kosovo Syndrome'. Geopolitics 14 (2), 219-234. doi:10.1080/ 14650040802693473

Beyoglu, Y. (2013). Yavru Vatanı Karşıtıran Yolsuzluk belgeleri.” Haber7. Online editionAvailable at: http://www.haber7.com/kibris/haber/995395-yavruvatani-karsitiran-yolsuzluk-belgeleri (Accessed October 15, 2021).

Blundell, D. (Editor) (2012). Taiwan since Martial Law. Berkeley, CA: University of California Press.

Brancati, D. (2016). Democracy Protests: Origins, Features, and Significance. New York, NY: Cambridge University Press.

Bucik, M. (2012). The Cyprus Problem: The Assessment of the 1997-2004 United Nations Mediation and the Rejection of the Annan Plan. "IAFF, 6171. (April)., no.

Buechler, S. M. (2011). Understanding Social Movements: Theories from the Classical Era to the Present. 1st edition. London New York: Routledge.

\section{DATA AVAILABILITY STATEMENT}

The original contributions presented in the study are included in the article/Supplementary Material, further inquiries can be directed to the corresponding author.

\section{AUTHOR CONTRIBUTIONS}

HU conducted all of the original research and writing associated with this paper.

Building Trust Civil Society, Trade and Cooperation in Cyprus (2011). Event Report. Nicosia, Cyprus: EC Cypriot Civil Society in Action Programme.

Burcher, C. U. (20172017). "Social Movements Are Here to Stay - a Part of Our Democratic Way of Life." IDEA - Internationa Institute for Democracy And Electoral Assistance (Blog). Available at: https://www.idea.int/news-media/news/socialmovements-are-here-stay-\%E2\%80\%93-part-our-democratic-way-life (Accessed October 15, 2021).

Bursztyn, L., Cantoni, D., Yang, D. Y., Yuchtman, N., and Zhang, Y. J. (2021). Persistent Political Engagement: Social Interactions and the Dynamics of Protest Movements. Am. Econ. Rev. Insights 3 (2), 233-250. doi:10.1257/ aeri.20200261

Carothers, T., and Press, B. (2020). "Worldwide Protests in 2020: A Year in Review." Online. A Year in Review. Carnegie Endowmen for International Peace. Available at: https://carnegieendowment.org/2020/12/21/worldwide-protestsin-2020-year-in-review-pub-83445.

Caspersen, N. (2011b). Democracy, Nationalism and (Lack of) Sovereignty: the Complex Dynamics of Democratisation in Unrecognised States $\uparrow$. Nations and Nationalism 17 (2), 337-356. doi:10.1111/j.1469-8129.2010.00471.x

Caspersen, N. (2012). Unrecognized States: The Struggle for Sovereignty in the Modern International System.

Caspersen, N. (2008). Separatism and Democracy in the Caucasus. Survival 50 (4), 113-136. doi:10.1080/00396330802329014

Caspersen, N. (2011a). "States without Sovereignty: Imitating Democratic Statehood," in In Unrecognized States In the International System. Editors N. Caspersen and R. V. Gareth(Milton Park, Abingdon, Oxon; New York: StansfieldRoutledge).

Chen, X., and Moss, D. M. (2018). "Authoritarian Regimes and Social Movements," in The Wiley Blackwell Companion To Social Movements (John Wiley \& Sons), 666-81, 666-681. doi:10.1002/9781119168577.ch38

Chenoweth, E., and Stephan, M. (2012). Why Civil Resistance Works: The Strategic Logic of Nonviolent Conflict. Reprint edition. New York, NY: Columbia University Press.

Chu, Y.-h. (1996). Taiwan's Unique Challenges. J. Democracy 7 (3), 69-82. doi:10.1353/jod.1996.0038

Cini, L., and Guzmán-Concha, C. (2017). Student Movements in the Age of Austerity. The Cases of Chile and England. Soc. Mov. Stud., 1-6. doi:10.1080/ 14742837.2017.1331122

Closson, S., Kolstø, P., Seymour, L. J. M., and Caspersen, N. (2013). Unrecognized States: the Struggle for Sovereignty in the Modern International System, by Nina Caspersen, Cambridge, Polity Press, 2012, 210 pp., $£ 55 / € 66 / \$ 69.95$ (Hardcover), £16.99/€20.40/\$24.95 (Paperback), ISBN-13 978-0-7456-53426. Natl. Pap. 41 (4), 675-683. doi:10.1080/00905992.2013.776527

Cordenillo, R., and Van der Staak, S. (2014). Political Parties and Citizen Movements in Asia and Europe. Stockholm, Sweden: International Institute for Democracy and Electoral Assistance.

Dahlum, S., and Tore, W. (2019). We Checked 100 Years of Protests in 150 Countries. Here's what We Learned about the Working Class and Democracy. "Washington Post, October 24, 2019, sec. Analysis Available at: https://www.washingtonpost.com/politics/2019/10/24/wechecked-years-protests-countries-heres-what-we-learned-about-workingclass-democracy/ (Accessed October 15, 2021).

Della Porta, D., and Tarrow, S. (2004). Transnational Protest and Global Activism. Maryland, United States: Rowman \& Littlefield Publishers. 
Della Porta, D., Diani, M., and Johnston, H. (2014). "The Game's Afoot", 1. Oxford Handbooks Online. doi:10.1093/oxfordhb/9780199678402.013.28

Dendere, C. (2019). Tweeting to Democracy: A New Anti-authoritarian Liberation Struggle in Zimbabwe. cea 38 (December), 167-191. doi: $10.4000 /$ cea.4507

Deng, F. M., Kimaro, S., Lyons, T., Rothchild, D., and William Zartman, I. (2010). Sovereignty as Responsibility: Conflict Management in Africa. Washington, DC: Brookings Institution Press.

Diamond, L. J. (2001). How Democratic Is Taiwan? Five Key Challenges for Democratic Development and Consolidation. New York, NY: Columbia University.

Duzgun, B. (2000). Cakil Taslari: Kibris'ta Bir Donemin Iz Dusumu (1990-2000). Istanbul, Turkey: Mart Matbaacilik.

Etzioni, A. (2006). Sovereignty as Responsibility. Orbis 50 (1), 71-85. doi:10.1016/ j.orbis.2005.10.006

Facal, G., and Estrelita, G. T. (2020). Social Movements Facing Authoritarian-Style Neoliberal Governments: Comparative Positioning towards Violence in Indonesia and France. Hum. 32 (3), 226. doi: $10.22146 /$ jh. 59555

Freeman-Woolpert, S. (20172017). "The History of Anti-authoritarian Struggle Is a History Worth Repeating." Waging Nonviolence (Blog). January 20. , 20172017 Available at: https://wagingnonviolence.org/2017/01/history-antiauthoritarian-struggles-history-worth-repeating/.

Garabli, A. (2015). "Dün Elinde Sandık, Bu Gün Dilinden Yandık Sn. Soyer. Ayşegül Garabli.” Detay Kıbrıs. Available at: http://www.detaykibris.com/dunelinde-sandik-bu-gun-dilinden-yandik-sn-soyer-76832yy.htm (Accessed October 15, 2021).

Gazeddakibris (2019). Incompatible Relationship: Crises between Akp and Turkish Cypriots. Translated by Esra Aygin. Gazeddakıbrıs, October 24, 2019, Online edition, sec. Available at: https://gazeddakibris.com/incompatible-relationshipcrises-between-akp-and-turkish-cypriots/.

Gazetesi, Y. (2011). Belediye Borca Batt1. Haber Kibris. October 21, 2011, Online edition, sec. Politics. Available at: http://haberkibris.com/202d21df-2011_10_ 21.html (Accessed October 15, 2021).

Gercek (2012). Kıbrıs'ta Polis Şiddetini Protesto eylemi. Gerçek Gazetesi. Occupy the Buffer Zone Movement. Available at: http://gercekgazetesi.net/genelhaberler/kibrista-polis-siddetini-protesto-eylemi (Accessed October 15, 2021).

Goldstone, J. A. (2004). More Social Movements or Fewer? beyond Political Opportunity Structures to Relational Fields. Theor. Soc. 33 (3/4), 333-365. doi:10.1023/B:RYSO.0000038611.01350.30

Groves, T. (2012). Everyday Struggles against Franco's Authoritarian Legacy: Pedagogical Social Movements and Democracy in Spain. J. Soc. Hist. 46 (2), 305-334. doi:10.1093/jsh/shs094

Gultasli, Selcuk. n. d. Kıbrıs'tan Bakınca Yolsuzluk manzaraları." ZAMAN. Available at: http://www.zaman.com.tr/yazarlar/selcuk-gultasli/kibristanbakinca-yolsuzluk-manzaralari_2190758.html (Accessed August 26, 2015). Online edition

Guven-Lisaniler, F., and Rodriguez, L. (2002). "The Social and Economic Impact on North Cyprus of Accession to the European Union," in The EU and Cyprus: Modern Conflict, Postmodern Union. Editor T. Diez. (Manchester, UK: Manchester University Press).

Guzman-Concha, C. (2012). The Student's Rebellion in Chile: Occupy Protest or Classic Social Movement. Soc. Mov. Stud. 11 (3-4), 408-415. doi:10.1080/ 14742837.2012.710748

Hallward, M. C., and Norman, J. M. (2015). Understanding Nonviolence. 1st edition. Polity.

Hannay, D. (2009). Cyprus: The Costs of Failure. London, UK: Centre for European Reform. Available at: http://homes.ieu.edu.tr/aburgin/IREU\% 20104\%20History\%20of\%20EU/Reading\%20Session\%2012_Cyprus\%20The $\% 20$ cost $\% 20$ of $\% 20$ failure.pdf.

Harvey, James., and Stansfield, Gareth. R. V. (2011). "Theorizing Unrecognized States: Sovereignty, Secessionism, and Political Economy," in " in Unrecognized States In the International System, 11-26. Editors Nina. Caspersen and R. V. Gareth(Milton Park, Abingdon, Oxon ; New York: StansfieldRoutledge).

Heydemann, S., and Leenders, R. (2013). Middle East Authoritarianisms: Governance, Contestation, and Regime Resilience in Syria and IranRedwood
City, UNITED STATES. Stanford University Press. Available at: http:// ebookcentral.proquest.com/lib/gmu/detail.action?docID $=1040651$.

Ho, M-s. (2018). The Activist Legacy of Taiwan's Sunflower Movement. Carnegie Endowment for International Peace. Available at: https:// carnegieendowment.org/2018/08/02/activist-legacy-of-taiwan-s-sunflowermovement-pub-76966.

Huang, T-y. (1998). Elite Transformation and Democratization in Taiwan. Texas:" PhDTexas A\&M.

ilter, T., and Alankuş, S. (2010). The Changing Configurations of Self-(m)Other Dialogue in North Cyprus. Social Identities 16 (2), 261-284. doi:10.1080/ 13504631003691116

Isachenko, Daria. (2012). The Making Of Informal States: Statebuilding In Northern Cyprus and Transdniestria. Rethinking Peace and Conflict Studies. Houndmills. Basingstoke, Hampshire; New York: Palgrave Macmillan.

Jackman, D. (2020). Students, Movements, and the Threat to Authoritarianism in Bangladesh. Contemp. South Asia 29 (0), 181-197. doi:10.1080/ 09584935.2020 .1855113

Jacobs, J. B., and Ben Liu, I.-H. (2007). Lee Teng-Hui and the Idea of "Taiwan". China Q. 190, 375-393. doi:10.1017/s0305741007001245

Jarraud, N. (2013). "Peacebuilding in Cyprus: What Is the Score?" Europe And CIS: UNDP (Blog). April 19, 2013Available at: http://europeandcis.undp.org/blog/ 2013/04/19/peacebuilding-in-cyprus-what-is-the-score/.

Johnston, H., and Paul, A. (2006). Latin American Social Movements: Globalization, Democratization, and Transnational Networks. New York, NY: Rowman \& Littlefield.

Kamenou, N., Ethemer, E., Costa, G., and Bullici, O. (2019). KIBRIS LGBTI HAREKETİ: Aktivizm, Hukuk Ve İki Kesimdeki Değişim. Bonn, Germany: Friedrich Ebert Foundation.

Kamilova, S., and Berg., E. (2012). "How Can a De Facto State Be Distinguished from a Puppet State? Analysis of Transnistrian-Russian Relations and Dependences," in Estonian Yearbook Of Foreign Policy (Estonia: Estonian Foreign Policy Institute), 227.

Kanol, D. (2014). "Tutelary Democracy in Unrecognized States." SSRN Scholarly Paper ID 2533621. Rochester, NY: Social Science Research Network. doi:10.2139/ssrn.2533621

Keck, M. E., and Sikkink, K. (2014). Activists beyond Borders: Advocacy Networks in International Politics. Activists beyond Borders. New York; London: Cornell University Press. doi:10.7591/9780801471292

Kopeček, V., Hoch, T., and Baar, V. (2016). De Facto States and Democracy: The Case of Abkhazia. Bull. Geogr. Socio-Economic Ser. 32 (32), 85-104. doi:10.1515/bog-2016-0017

Ladini, G. (2009). Peacebuilding, United Nations and Civil Society: The Case of Cyprus. Cyprus Rev. 21 (2), 37.

Lee, F. L. F. (2010). The Perceptual Bases of Collective Efficacy and Protest Participation: The Case of Pro-democracy Protests in Hong Kong. Int J. Public Opin. Res. 22 (3), 392-411. doi:10.1093/ijpor/edq023

Lin, H-t. (2016). Accidental State: Chiang Kai-Shek, the United States, and the Making of Taiwan. Boston, USA: Harvard University Press.

Lin, T-c. (2005). Transforming State-Society Relations: The Challenge, Dilemma and Prospect of Civil Society in Taiwan." Annual Report. An Assessment of Civil Society in Taiwan. Taiwan: Center for International NGO Studies, National Sun Yat-sen University \& CIVICUS.

Lomsadze, G. (2014). Abkhazia: The Post-Soviet Revolution the World Blinked and Missed. Online. Eurasianet/Guardian: Carnegie Endowmen for International Peace Available at:https://carnegieendowment.org/2014/06/09/ abkhazia-post-soviet-revolution-world-blinked-and-missed-pub-55894.

Lonnqvist, L. (2008). Civil Society in Reconciliation: Beyond the 'Cyprus Problem. INTRAC Policy Briefing Paper 21. Oxford, United Kingdom: INTRAC.

Mahoney, J., and Rueschemeyer, D. (2003). in Comparative Historical Analysis in the Social Sciences. Cambridge Studies in Comparative Politics (Cambridge, UK; New York: Cambridge University Press).

McAdam, D. (2010). Political Process and the Development of Black Insurgency, 1930-1970. University of Chicago Press.

McCarthy, J. D., and Zald, M. N. (2001). "The Enduring Vitality of the Resource Mobilization Theory of Social Movements," in " in Handbook Of Sociological Theory. Editor J. H. Turner (Boston, MA: Springer US), 533-565. doi:10.1007/ 0-387-36274-6_25 
Meseznikov, G. (2013). Democratization and Civil Society Development in Taiwan: Some Lessons for Central Europe Working Paper. Slovakia: Institute for Public Affairs.

Mikhelidze, N., and Pirozzi, N. (2008). Civil Society and Conflict Transformation in Abkhazia, Israel/Palestine, Nagorno-Karabakh, Transnistria and Western Sahara. Policy Working Paper, no. 3, MICROCON: A Micro Level Analysis of Violent Conflict, Institute of Development Studies. Brighton: University of Sussex, 85.

Moses, J. (2014). Sovereignty and Responsibility: Power, Norms and Intervention in International Relations.

Mulaj, K. (2011). "International Actions and the Making and Unmaking of Unrecognized States," in " in Unrecognized States In the International SystemNina Caspersen and Gareth R. V. Stansfield, 41-57 (Milton Park, Abingdon, Oxon ; New York: Routledge).

Northern Cyprus Country Report 2002 (2003). Freedom in the World. Washington DC, USA: Freedom House. Available at: https://freedomhouse.org/report/ freedom-world/2002/northern-cyprus.

Northern Cyprus Country Report 2011 (2012). . Freedom in the World. Washington DC, USA: Freedom House. Available at: https://freedomhouse. org/report/freedom-world/2011/northern-cyprus.

Ozadam, L. (2014). İşte Yolsuzluk, Hadi CTP!’ Kibris Postasi, August 29, 2014. Online editionAvailable at: http://www.kibrispostasi.com/index.php/cat/1/col/ 147/art/22663/PageName/KIBRIS_POSTASI.

Panov, L., and Varon, L. (2017). "An Assessment of Civil Society in Environment in the Northern Part of Cyprus." Evaluation. Nicosia, Cyprus: Sivil Alan/Civic Space.

Petras, J., and Veltmeyer, H. (2011). "Neoliberalism and the Social Movements: Mobilizing the Resistance,". Editors J. Petras and H. Veltmeyer (New York: Palgrave Macmillan US), 79-117, 79-117. doi:10.1057/9780230117075_5Social Movements Latin America

Pinckey, J. (2020). "Amid Coronavirus, Online Activism Confronts Digital Authoritarianism." United States Institute of Peace (Blog). April 28, 2020 Available at: https://www.usip.org/publications/2020/04/amid-coronavirusonline-activism-confronts-digital-authoritarianism.

Pugliese, M. (2015). Abkhazia, from Political Crisis to the New Military Treaty with Russia. Academic Security Forum Warsaw, January 24, 2015.

Repucci, S., and Amy, S. (2021). "Democracy under Siege." Online. Freedom in the World. Washington DC, USA: Freedom House. Available at: https:// freedomhouse.org/report/freedom-world/2021/democracy-under-siege.

Sa'di, A. H. (2015). Social Protest under Authoritarianism: A Critique of Regime Type and Instrumental Rationality-Based Explanations. Sociology 49 (3), 455-470. doi:10.1177/0038038514540372

Skocpol, T. (1979). States and Social Revolutions: A Comparative Analysis of France, Russia and China. Cambridge; New York: Cambridge University Press.

Skocpol, T. (2006). States and Social Revolutions: A Comparative Analysis of France, Russia, and China. New York: Cambridge University Press. Available at: http://mutex.gmu.edu/login?url=http://hdl.handle.net/2027/heb. 03295.

Smith, J., and Wiest, D. (2012). Social Movements in the World-System: The Politics of Crisis and Transformation. New York: Russell Sage Foundation.

Smith, J. (1998). Global Civil Society. Am. Behav. Scientist 42 (1), 93-107. doi:10.1177/0002764298042001008

Smooha, S. (2010). The Model of Ethnic Democracy: Israel as a Jewish and Democratic State. J. Sino - West. Commun. 2 (S1), 77-104.

Theophylactou, D. A. (2012). Geopolitics, Turkey's EU Accession Course and Cyprus: Power Balances and 'Soft Power' Calculations. Southeast Eur. Black Sea Stud. 12 (1), 97-114. doi:10.1080/14683857.2012.662346

Tilly, C. (1992). Coercion, Capital and European States: AD 990 - 1992. Revised edition. Cambridge, MA: Wiley-Blackwell.

Tilly, C. (2004a). Contention And Democracy In Europe, 1650-2000. Cambridge Studies in Contentious Politics. Cambridge, UK ; New York: Cambridge University Press. http://mutex.gmu.edu/login?url=http://search.ebscohost. com/login.aspx?direct $=$ true\&scope $=$ site\&db=nlebk\&db=nlabk\&AN=152248.

Tilly, C. (1978). From Mobilization to Revolution. Reading, Mass: Addison-Wesley.

Tilly, C. (2003). Inequality, Democratization, and De-democratization. Sociological Theor. 21 (1), 37-43.
Tilly, C. (2004b). Observations of Social Processes and Their Formal Representations. Sociological Theor. 22 (4), 595-602.

Tilly, C. (2000). Processes and Mechanisms of Democratization. Sociological Theor. $18(1), 1-16$

Trejo, G. (2014). The Ballot and the Street: An Electoral Theory of Social Protest in Autocracies. Persp Pol. 12 (2), 332-352. doi:10.1017/S1537592714000863

Ulas, H. (2014). "An Unrecognized Aspect of Conflict: Isolationism and Resolution in Cyprus," in The New Generation of Ideas (Boston, MA: UMass Boston), Vol. 10.

Ulas, H. (2016). Donors and De Facto States: A Case Study of Un Peacebuilding in the Self-Declared Turkish Republic of Northern Cyprus. J. Peacebuilding Dev. 11 (1), 75-80. doi:10.1080/15423166.2016.1149091

Ulas, H. (2017). The Democratization of Unrecognized States: A Comparative Study. Washington, DC: "Doctoral DissertationGeorge Mason University.

Ulas, Hilmi. (2012). The Question of Cultural Genocide and Racism: Personal Reflections on the Case of Northern Cyprus." Text. Beyond Intractability. Available at: https://www.beyondintractability.org/casestudy/ulas-questioncultural-genocide-racism.

Understanding and Challenging Authoritarianism (2017). Workshop Report. War \& Pacification. Amsterdam, Netherlands: The Transnational Institute. Available at: https://www.tni.org/en/publication/understanding-and-challenging-authoritarianism.

Vidwans, P. (2020). The Best Hope We Have.' the Promise of Protest Movements Going Global. July 2. World Politics Review (blog). Available at: https://www. worldpoliticsreview.com/trend-lines/28889/the-best-hope-we-have-the-promiseof-protest-movements-going-global.

Voller, Y. (2015). Contested Sovereignty as an Opportunity: Understanding Democratic Transitions in Unrecognized States. Democratization 22 (4), 610-630. doi:10.1080/13510347.2013.856418

Wang, K.-C. (1992). Democratization in Taiwan: The Interaction of Structure, Political Institutions, and Political Elites. Philadelphia: PhDUniversity of Pennsylvania.

Williams, P. R. (2002). Earned Sovereignty: The Road to Resolving the Conflict over Kosovo's Final Status. Denver J. Int. L. Pol. 31 (3), 387-426.

Williams, P. R., Scharf, M. P., and Hooper., J. R. (2002). Resolving SovereigntyBased Conflicts: The Emerging Approach of Earned Sovereignty. Denver J. Int L. Pol. 31 (3), 349-354.

Wolff, S. (2011). "The Limits of International Conflict Management in the Case of Abkhazia and South Ossetia," in " in Unrecognized States In the International System, 147-64. Editors Nina. Caspersen and R. V. Gareth (Milton Park, Abingdon, Oxon ; New York: StansfieldRoutledge).

Yesilada, B. A., and Sozen, A. (2002). Negotiating a Resolution to the Cyprus Problem: Is Potential European Union Membership a Blessing or a Curse. Int. Negotiation 7 (2), 261-285. doi:10.1023/a:1021296723063

Yiftachel, Oren, and Professor Department of Geography and Environmental Development Oren Yiftachel (2006). Ethnocracy: Land and Identity Politics in Israel/Palestine. University of Pennsylvania Press.

Yusuf, H. M. (20132013). KKTC’de Yolsuzluk, Arsızlık, Yüzsüzlük ve Pişkinlik. Available at: http://karsiyorum.blogcu.com/kktc-de-yolsuzluk-arsizlik-yuzsuzlukve-piskinlik/1814991.

Conflict of Interest: The author declares that the research was conducted in the absence of any commercial or financial relationships that could be construed as a potential conflict of interest.

Publisher's Note: All claims expressed in this article are solely those of the authors and do not necessarily represent those of their affiliated organizations, or those of the publisher, the editors and the reviewers. Any product that may be evaluated in this article, or claim that may be made by its manufacturer, is not guaranteed or endorsed by the publisher.

Copyright $(2021$ Ulas. This is an open-access article distributed under the terms of the Creative Commons Attribution License (CC BY). The use, distribution or reproduction in other forums is permitted, provided the original author(s) and the copyright owner(s) are credited and that the original publication in this journal is cited, in accordance with accepted academic practice. No use, distribution or reproduction is permitted which does not comply with these terms. 